Relations industrielles

Industrial Relations

\title{
Martin, Andrew, George Ross et al., The Brave New World of European Labor: European Trade Unions at the Millennium
}

\section{Leo Panitch}

Volume 55, numéro 3, 2000

URI : https://id.erudit.org/iderudit/051339ar

DOI : https://doi.org/10.7202/051339ar

Aller au sommaire du numéro

Éditeur(s)

Département des relations industrielles de l'Université Laval

ISSN

0034-379X (imprimé)

1703-8138 (numérique)

Découvrir la revue

Citer ce compte rendu

Panitch, L. (2000). Compte rendu de [Martin, Andrew, George Ross et al., The Brave New World of European Labor: European Trade Unions at the Millennium]. Relations industrielles / Industrial Relations, 55(3), 545-547. https://doi.org/10.7202/051339ar

Tous droits réservés (C Département des relations industrielles de l'Université Laval, 2000
Ce document est protégé par la loi sur le droit d'auteur. L'utilisation des services d'Érudit (y compris la reproduction) est assujettie à sa politique d'utilisation que vous pouvez consulter en ligne.

https://apropos.erudit.org/fr/usagers/politique-dutilisation/ 
la syndicalisation française dans les grands établissements est d'ailleurs pour l'essentiel due aux syndicats à leadership radical alors que les syndicats dont l'idéologie est plus modérée réalisent des performances similaires à celles de leurs homologues d'outre Atlantique.

La thèse défendue par Friedman est donc fondée sur trois positions fortes. Elle reprend tout d'abord l'hypothèse historique que les mouvements ouvriers sont d'abord politiques et s'enracinent historiquement dans l'utopie de l'achèvement du processus démocratique révolutionnaire initié par la révolution française et le mouvement des droits américains. Elle réaffirme la centralité des conflits et de la structure des positions respectives qu'ils produisent dans l'explication des phénomènes d'institutionnalisation, y compris sur longue période. Elle s'oppose avec vigueur aux différents réductionnismes économiques, y compris ceux des marxismes orthodoxes ou des pères fondateurs de l'institutionnalisme américain.

Appuyés sur des traitements statistiques très solides, nombre de raisonnements de détail apportent des éléments de preuve fort convaincants. Il faudrait parfois descendre dans le détail de la définition des dummy variables pour discuter tel ou tel point qui mériteraient une discussion plus approfondie : ainsi les taux de syndicalisation sont parfois calculés sur des branches locales et non établissement par établissement et peuvent donc masquer des différences d'implantation notables dans certains cas d'espèce. Ces traitements statistiques sont relayés par des analyses politiques larges d'une grande précision. Certains historiens discuteront de la possibilité de construire ainsi des explications de large portée, tant parce qu'elles couvrent de longues périodes que parce qu'elles englobent des situations nationales qui peuvent paraître hétérogènes. Mais ceci ne retire rien à la valeur et à la profondeur de la thèse qui nous est ici proposée et qui constitue une contribution majeure et incontournable aux débats sur la syndicalisation et sur son explication historique et plus largement à l'histoire économique comparée.

JEAN SAGLio CNRS-CRISTO, Université Pierre Mendès-France

\section{The Brave New World of European Labor: European Trade Unions at the Millennium}

by Andrew Martin and George Ross, et al., New York: Berghahn Books, 1999,416 p, ISBN 1-57181-167-2 (hc.: alk. paper) and ISBN 1-57181-1680 (pbk.: alk. paper).

Anyone looking for an in-depth, upto-date and balanced account of trade unions in Europe, covering the last two decades of the $20^{\text {th }}$ century, need look no further than the six studies of Britain, Germany, Sweden, France, Italy and Spain brought together here under the coordination by Andrew Martin and George Ross. Particularly outstanding are the essays on Britain and Sweden by Chris Howell and Rianne Mahon respectively: I am aware of no more comprehensive and insightful accounts of the deep crisis that enveloped these two la- bour movements since 1980 . And the fact that Martin and Ross themselves contribute an essay of equal quality on labour representation at the level of the EU makes this book a definitive text on contemporary European trade unionism.

The book is not only important for the European specialist. A great many people everywhere look to Europe as providing the answer of how labour should respond to globalization. Despite the many defeats European unions have suffered at the national level, it is believed that the European Social 
Protocol provides a model for securing the inclusion of labour rights in international economic treaties, thereby 'constitutionalizing' minimum labour standards as well as securing a place for labour representatives in the negotiation and administration of these treaties. While not unsympathetic to such an approach, Martin and Ross conclusively demonstrate that those who look to labour achievements at the regional level in Europe must be basing themselves on superficial knowledge of what really is going on.

What the European Trade Union Congress (ETUC) saw as its 'breakthrough, beyond anything it could have reasonably expected' when it was suddenly embraced as a negotiating partner under Maastricht's Social Protocol, soon proved, Martin and Ross show, to be only a breakthrough for the union bureaucracy in Brussels. The embrace 'turned out very different from what enthusiasts had foreseen in the heady days of 1985 to $1990^{\prime}$ and left the ETUC 'essentially excluded from more fundamental matters of economic governance.' This was reflected in the sheer weakness of the Social Protocol actually negotiated under Maastricht (especially insofar as matters concerning pay or the rights to organize and strikes were entirely excluded). Even the much-vaunted subsequent protocol mandating European Works Councils in MNCs (which covered only some ten percent of the European workforce in any case), left so much lee-way to employers that it produced 'less than a handful of agreements [which] provide for consultation more meaningful... than an "exchange of views" after the fact.' Despite some modest success in the area of parental leave benefits, Martin and Ross show that there can be no escaping the fact that 'the EMU macroeconomic policy regime has squeezed social policy between unemployment and convergence/ stability pact criteria' to such an extent that capitalist 'supply-side' strategies for greater labour market 'flexibility' have come to take precedence over any positive new strategy for labour (p. 312339).

Martin and Ross also show that labour's involvement in European integration has been 'largely a top-down process.' As they put it: 'The ETUC has so far developed largely by borrowing resources from European institutions to gain legitimacy with its own national constituents... ETUC, in other words, has developed from the top rather than as a mass organization built from below out of a broader social movement.' Moreover, since the promise of substantial gains from elite bargaining within European institutions has not materialized, the result has been that the European unions' position of 'critical support' for Economic and Monetary Union 'has so far put them in an excruciating political bind. It ties them to the particular version of the economic approach to political integration that has been pursued despite its social costs and rising popular disenchantment, including among union members.' Not surprisingly in this context, unions have relied on national collective bargaining and political structures to protect themselves as best they could. But the 'competitive corporatism' they are still oriented to at this level, seen in various new 'social pacts' that have been struck with employers and the state, has mainly to do with competitive adjustment (via the sacrifice of earlier labour market and welfare state reforms as well as wage moderation) to the neo-liberalism embedded in European integration (p. 352358).

What then is to be done? Unfortunately, those who are looking for the answer to this will have to content themselves with the sober account of European labour provided here and look elsewhere for strategic direction. This book's weakness in this respect, despite its great descriptive strength, appears to be a direct function of its lack of clear 
theoretical focus. The one concept that is (somewhat mechanically) used to links all the essays - the 'double shift', referring to the process whereby, since 1980, '[s]imultaneously, decisions most important to unions moved away from the national arenas "upward" towards transnational arenas and "downward" towards subnational ones, transferring matters from arenas where unions could be effective towards those where they were weaker' - is itself descriptive rather than explanatory. A brief survey of the limits of various 'schools' of analysis (industrial relations, political economy, etc.) is offered by Martin and Ross in an introductory essay but the treatment of each is cursory and nothing is put in their place, except the need to "work at a lower level of abstraction to study the choices of a limited number of actors at a given time'. The justification for this is that 'the world of unions is not easily reducible to parsimonious analysis' (p. 4-8).

To which the answers must be: what is? and who ever said it was easy to theorize and strategize? Moreover, even the best empiricist needs a theory and usually has an unelaborated one lurking around somewhere. As far as I can tell the one lurking in most, although not all, of the essays here, is that of Marxist class analysis, even though, in their introductory essay, Martin and Ross ostensibly dismiss this approach: 'Marxists see unions as organised intermediaries between the "working class" and capitalists whose performance is measured by the degree to which they promote "class interests"... Marxists are thus troublesome because they tend to be reductionist, looking not at what unions do but how closely they approximate the pursuit of "class interests" assumed a priori' (p. 5). Yet, despite the scare quotes and the derision, every essay in this volume - and especially best ones by Howell, Mahon and Martin and Ross themselves - is clearly operating on the basis of a notion of working class interest, conceived not only in terms of the weakening of labour vis-à-vis capital being something bad for working people, but even in terms of some notion of liberating workers from the logic of capitalist domination and competition being a good thing. It is unfortunate indeed that we have come to live in an academic climate today when those scholars who have the most experience, talent and resources to observe European working classes most closely and perceptively do so without contributing to developing and improving the very Marxist theory and strategy whose foundational ideas and ideals still implicitly motivate and guide their studies.

Leo Panitch York University

\section{La CSN : 75 ans d'action syndicale et sociale}

sous la direction d'Yves Bélanger et Robert Comeau, Sainte-Foy : Presses

de l'Université du Québec, 1998, 339 p., ISBN 2-7605-0965-6.

Cet ouvrage est composé de textes issus d'un colloque tenu à l'Université du Québec à Montréal, au printemps 1997, à l'occasion du $75^{\circ}$ anniversaire de la Confédération des syndicats nationaux (CSN).

Les actes de ce colloque sont divisés en quatre parties. Les deux premières parties de l'ouvrage sont essentiellement consacrées à l'histoire de la CSN. Les deux autres parties du livre font état des orientations actuelles de la Centrale ainsi que des nouvelles avenues qui s'ouvrent au syndicalisme.

La première partie historique du volume porte sur la CSN et l'évolution du mouvement ouvrier au Québec. Les thèmes abordés traitent des origines de la centrale syndicale (CTCC) et de son évolution jusqu'à la Deuxième Guerre 